\title{
Basil conservation affected by cropping season, harvest time and storage period
}

\author{
Franceli da Silva(1), Ricardo Henrique Silva Santos ${ }^{(1)}$, Nélio José de Andrade ${ }^{(1)}$, Luiz Cláudio Almeida Barbosa ${ }^{(1)}$, \\ Vicente Wagner Dias Casali ${ }^{(1)}$, Renato Ribeiro de Lima ${ }^{(1)}$ and RicardoVaz de Melo Passarinho ${ }^{(1)}$
}

(1)Universidade Federal de Viçosa, Dep. de Fitotecnia, CEP 36570-000 Viçosa, MG, Brazil. E-mail: rsantos@ufv.br, nandrade@ufv.br, Icab@ufv.br, vwcasali@ufv.br, rrlima@ufv.br

\begin{abstract}
Fresh basil (Ocimum basilicum L.) is used in food, phytotherapic industry, and in traditional therapeutic, due to its essential oil content and composition. Nevertheless basil can not be kept for long periods after harvest and its quality can be reduced. This work aimed to assess the influence of the season and harvest time in the postharvest conservation of basil stored for different periods. Basil was harvested at 8 am and 4 pm both in August/1999 and January/2000. Cuttings were conditioned in PVC packages and stored for 3, 6, and 9 days. During storage, chlorophyll content, essential oil content and composition were determined as well as microbiological analyses were carried out. Harvest season and the days of storage influenced the final content of essential oil. There was a linear decrease in the content of essential oil, in the chlorophyll content and in the number of mold and yeast colonies during storage. There was no effect of cropping season or harvest hour on essential oil composition, but the eugenol and linalool content increased during storage. Coliforms were under $0.3 \mathrm{MPN} \mathrm{g}^{-1}$ and the number of Staphylococcus aureus was under $1.0 \times 10^{2} \mathrm{UFC} \mathrm{g}^{-1}$.
\end{abstract}

Index terms: Ocimum basilicum, eugenol, linalool, chlorophyll, mold, yeast.

\section{Armazenamento e conservação de manjericão após diferentes épocas e horários de colheita}

\begin{abstract}
Resumo - O manjericão (Ocimum basilicum L.) é empregado tanto na indústria culinária quanto fitoterápica e na medicina tradicional, devido ao teor e composição de seu óleo essencial. No entanto, o manjericão não pode ser conservado por longo período após a colheita e sua qualidade pode ser prejudicada. O objetivo deste trabalho foi verificar a influência da época e do horário de colheita sobre a conservação de manjericão armazenado por diferentes períodos. O manjericão foi colhido às $8 \mathrm{~h}$ e às $16 \mathrm{~h}$ em agosto/1999 e em janeiro/2000. Os ramos foram acondicionados em filmes de PVC e armazenados por 3, 6 e 9 dias. Durante o armazenamento, o teor de clorofila, e o teor e a composição do óleo essencial foram determinados e foram conduzidas análises microbiológicas. A época de colheita e os dias de armazenamento influenciaram o teor final de óleo essencial. Houve decréscimo linear dos teores de óleo essencial e de clorofila e do número de colônias de fungos e bactérias ao longo do armazenamento. Não houve efeito da época de colheita ou do horário de colheita sobre a composição do óleo essencial, mas os teores de eugenol e linalol aumentaram durante o armazenamento. O número de coliformes ficou abaixo de 0,3 NMP g-1 e o número de Staphylococcus aureus, abaixo de 1,0x10² UFC g .
\end{abstract}

Termos para indexação: Ocimum basilicum, eugenol, linalol, clorofila, fungos, bactérias.

\section{Introduction}

The use of fresh basil (Ocimum basilicum L.) in food, phytotherapic industry, and in traditional therapeutic is frequently reported (Vieira \& Simon, 2000; Miele et al., 2001a, 2001b). This interest is due to the presence of essential oil in superficial glands and trichomes (Gang et al., 2001), whose main components can be eugenol, methyleugenol, linalool, methylchavicol, or 1,8-cineole, depending on factors as chemotype, growth conditions and plant developing stage (Bahl et al., 2000; Lewinsohn et al., 2000; Nacar \& Tansi, 2000; Vieira \& Simon, 2000; Miele et al., 2001a, 2001b). Nevertheless, just as other leafy herbs, basil can not be kept for long periods after harvest and the essential oil content and quality can be reduced during postharvest. The main cause of losses is endogenous, though external factors as chilling injury may contribute (Lange \& Cameron, 1994, 1997).

Senescence of the tissues is a result of the oxidation of many compounds, like proteins, lipids and chlorophyll. 
Chlorophyll content is used for monitoring the senescence process and postharvest conservation (Cantwell \& Reid, 1994; Philosoph-Hadas et al., 1994; Meir et al., 1997). Besides, senescence is followed by an increase of activity of the peroxidases and polyphenoloxidases enzymes, which are responsible for darkening tissues (Underhill \& Critchley, 1995). Postharvest leaf conservation of herbs as basil is also influenced by the harvest hour (Lange \& Cameron, 1994), due to the fact that greater sugar contents present in the afternoon contribute to maintain the metabolic activity and a better tissue conservation.

Climatic conditions as well as other factors like damage caused by fungi, presence of disease-causing microorganisms, and a careful handling and transportation can also determine the level of postharvest loss (Kays, 1991). Better environmental conditions as controlled temperature, air circulation, relative humidity and the composition of the atmosphere can be obtained by packing vegetables in plastic films and storage in cold chambers. The utilization of herbs pre-packed in PVC film is recent in Brazil but it offers a great potential for growth, since it allows saving time and provides material for fast food restaurant nets. The processing serves customers that look for ready-to-consume, fresh looking and free from chemical conservants vegetables - a world-wide trend (Luengo \& Lana, 1997).

The present work aimed to assess the postharvest conservation of $O$. basilicum, harvested in two different seasons and in two different day hours, stored for different periods.

\section{Material and Methods}

Plants of $O$. basilicum were cultivated at the Medicinal Herbs Garden of Plant Science Department, Universidade Federal de Viçosa (UFV), MG, Brazil, located at $20^{\circ} 45^{\prime} \mathrm{S}, 42^{\circ} 51 \mathrm{\prime} \mathrm{W}$ and at $651 \mathrm{~m}$ above the sea. Seedlings were obtained from one original plant, transplanted on April 14, 1999, and cultivated until January 2000.

In August and January, three plots were harvested at $8 \mathrm{am}$, and other three at $4 \mathrm{pm}$. The terminal shoots $(15 \mathrm{~cm})$ of each plant were collected, conditioned in previously $70 \%$ alcohol cleaned trays and taken to the laboratory. There, damaged and insect attacked shoots were eliminated. After the selection, the shoots were washed in cleaned trays containing cold water $\left(2^{\circ} \mathrm{C}\right)$ for 15 minutes in order to reduce the field heat and the microbial load.
The shoots were kept in the lab for two hours until the complete drying of the leaf surface. Then $30 \mathrm{~g}$ of shoots were conditioned in a PVC package measuring $19.5 \times 17.0 \mathrm{~cm}$. The package was shut and immediately taken to cold chamber at $10^{\circ} \mathrm{C}$, where samples were stored for 9 days and data collected on a three-day basis.

The chlorophyll content was assessed by means of a portable meter, with Spad units, on all stored shoots. Data from 20 randomly chosen leaves were taken from each sample, which generated the value of the plot.

Plants harvested in January 2000 in the morning were used in the microbiological evaluation, and were stored for 9 days in PVC packages at $10^{\circ} \mathrm{C}$, and data was collected on a three-day basis. Microbiological analysis was made in the UFV Food Technology Department. At $0,3,6$ and 9 days after storage, $11 \mathrm{~g}$ samples of the product were taken from each plot. They were homogenized for $1 \mathrm{~min}$ in $0.01 \%$ peptone water, $\mathrm{pH} 7.0 \pm 0.1$, and aliquots of appropriate decimal dilutions were inoculated in the specific culture media for microbial groups.

The microbiological analyses followed the methods as proposed by Vanderzant \& Splittstoesser (1992). The number of yeasts and molds (UFC $\mathrm{g}^{-1}$ ) was determined in the acidified potato dextrose agar, $\mathrm{pH} 3.5$, after incubation at $25^{\circ} \mathrm{C}$ for 72 hours. The more probable number (MPN) of total coliform was determined in the brilliant green bile lactose $2 \%$ broth after incubation at $35^{\circ} \mathrm{C}$ for 24 to 48 hours. Fecal coliform MPN was determined in Escherichia coli broth (EC) after incubation at $45.5 \pm 0.2^{\circ} \mathrm{C}$ for 24 to 48 hours. Aliquots of positive tubes in EC broth were inoculated in triptone broth and, after incubation, fecal coliform was confirmed by gas and indol presence. The number of Staphylococcus aureus was determined in Baird-Parker Agar after incubation at $35^{\circ} \mathrm{C}$ for $30-48$ hours. All colonies which were black and shiny with narrow white margins and surrounded by clear zones extending into the opaque medium were considered to be $S$. aureus.

The essential oil content was determined at harvest and during storage in shoots harvested in both cropping seasons and both day hours. The extraction of the essential oil was made at the UFV Chemistry Department, through the steam distillation method (Martins et al., 1997; Kamada et al., 1999). The distillation time was approximately 120 minutes, $30 \mathrm{~g}$ of fresh plants randomly chosen from each plot were used for extraction and $1 \mathrm{~L}$ of hydrolate was collected. The essential oil was extracted with pentane $(3 \times 50 \mathrm{~mL})$. The 
organic phase was dried up with magnesium sulfate and starch and filtered. The solvent was removed in reduced pressure in rotative evaporator. The percentage of oil in relation to the dry matter of the plant was calculated. This was obtained by drying $30 \mathrm{~g}$ of the plant sample to $70^{\circ} \mathrm{C}$, at a sterilizer with forced air circulation until a constant weight. The extraction of the oil was carried out on days $0,3,6$ and 9 of the product storage.

The essential oil whole composition was determined in shoots harvested in both cropping seasons and both day hours. During storage, the relative content of the two major components eugenol and linalool was determined. Samples of essential oil were stored under refrigeration and protected from light in glass flasks with screwed caps and sealed with parafilm; they were then analyzed by means of chromatography in gas phase. A chromatographer equipped with fire ionization detector (FID) and capillary tubes SBP-5 (30 m length and $0.25 \mathrm{~mm}$ of internal diameter) was used. The plunging gas was nitrogen. The initial temperature of the column was $60^{\circ} \mathrm{C}$, kept for 1 minute and, from that moment on, programmed to raise $3^{\circ} \mathrm{C}$ each minute until the maximum temperature of $240^{\circ} \mathrm{C}$. The temperatures of the injector and detector were fixed at $220^{\circ} \mathrm{C}$ and $240^{\circ} \mathrm{C}$ respectively. The oil samples were weighed (10 mg) and diluted in $1.0 \mathrm{~mL}$ of pentane, and $1 \mu \mathrm{L}$ of this sample was injected in the chromatographer.

The operational conditions used in the mass spectrometry were: tube DB 5 (30 m long and $0.25 \mathrm{~mm}$ of inner diameter); injector temperature $\left(220^{\circ} \mathrm{C}\right)$; detector temperature $\left(240^{\circ} \mathrm{C}\right)$; temperature program of $60^{\circ} \mathrm{C}-240^{\circ} \mathrm{C}$ for 3 minutes and $240^{\circ} \mathrm{C}$ for 15 minutes; plunging gas $\mathrm{He}\left(1 \mathrm{~mL} \mathrm{~min}^{-1}\right)$; split ratio 1:20; injected volume $(1 \mu \mathrm{L})$; electronic impact energy $(70 \mathrm{eV})$; and collected fragments (45 to $650 \mathrm{Da}$ ). Constituents with concentration lower than $1 \%$ were not considered. The identification of the compounds was obtained by comparing the mass spectra obtained with those from the equipment (Wiley 140000) data bank and by the Kovats index of each component (Adams, 1995).

The experimental design was entirely casualized in a split plot design with three repetitions and three plants per plot. The plot treatments were the factorial $2 \mathrm{x} 2$, with two seasons as well as two harvest hours and the subplots were the days of the postharvest storage. Data were submitted to analysis of variance and regression at the level of $5 \%$ of probability using the SAEG - Statistical and Genetics Analyses System (Ribeiro Junior, 2001).

\section{Results and Discussion}

The content of essential oil in the postharvest was influenced by the season of harvest and by the days of storage of the product. There was no significant effect of the harvesting hour. Shoots harvested in January presented greater essential oil content $(2.26 \%)$ than shoots harvested in August (1.06\%). Shoots presented a linear decrease in the oil content along the storage period in these months (Figure 1).

There was no effect of cropping season and harvest hour on composition and content of essential oil major components, which identification is shown in Table 1. The two major components of the essential oil were eugenol and linalool.

The eugenol and linalool relative content increased during storage (Figure 2). The eugenol content increased sharper than linalool content, and both components presented the highest content at the end of storage period.

Shoots presented a similar decrease in the chlorophyll content along the days of storage in both cropping season. The degradation of the chlorophyll did not differ between harvest hours and presented a linear decrease of 0.4209 Spad units per day of storage (Figure 3).

For all basil samples, the numbers of total and fecal coliform were $<0.3 \mathrm{MPN} \mathrm{g}^{-1}$ and the numbers of $S$. aureus were $<1.0 \times 10^{2} \mathrm{UFC} \mathrm{g}^{-1}$. The regression analysis indicated a reduction of 0.1291 logarithmic cycle in the number of moulds and yeasts, expressed in UFC $\mathrm{g}^{-1}$ of product, in each day of storage at $10^{\circ} \mathrm{C}$, in PVC package (Figure 4).

After 9 days of storage, plants harvested in January contained higher oil content than the plants harvested in

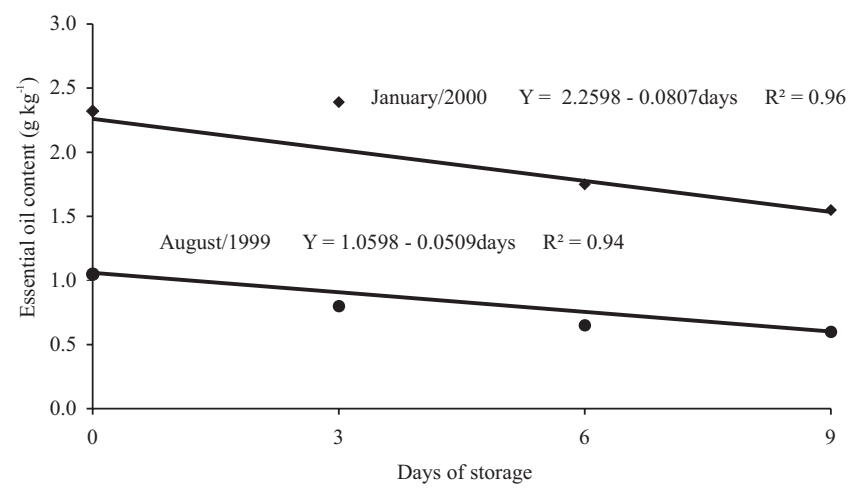

Figure 1. Fresh basil essential oil content along storage at $10^{\circ} \mathrm{C}$ in two cropping seasons. Data represent means of two harvest hours and of three repetitions during the storage periods. 
August, due to its higher initial oil content. West (1990) observed that Mentha species, when stored for a long period, suffered changes in the ultrastructure of the glands, and the content of essential oil was reduced. Shalaby et al. (1988) observed a variation in the content of essential oil of Mentha arvensis during the storing period. However, these authors relate to alterations in the contents of menthol in the essential oil, which is not the case of the present work.

Basil plants synthesize and store essential oil in superficial peltate glands and trichomes (Gang et al., 2001); therefore, along the days of storage, there might have been loss caused by volatilization, even at low temperature. Along a linear decrease in essential oil content, plants presented a decrease in the content of chlorophyll along the days of storage, as in the data reported by Cantwell \& Reid (1994). The same authors, assessing the postharvest physiology of fresh basil herbs stored at $0^{\circ} \mathrm{C}, 10^{\circ} \mathrm{C}$ and $20^{\circ} \mathrm{C}$, observed that basil had a better appearance at $10^{\circ} \mathrm{C}$ and received grade 8 , which means good quality. However, it received grade 2 when conserved at $0^{\circ} \mathrm{C}$ because it was cold damaged; and at $20^{\circ} \mathrm{C}$, it received grade 7 , which means good quality but

Table 1. Identification and content (\% of area) of the components of essential oil extracted from fresh basil (Ocimum basilicum) cultivated in Viçosa, MG, Brazil, at two cropping seasons and two day hours( ${ }^{(1)}$.

\begin{tabular}{|c|c|c|c|c|c|}
\hline \multirow[t]{3}{*}{ Component } & \multirow{3}{*}{$\begin{array}{l}\text { Kovats } \\
\text { index }\end{array}$} & \multicolumn{4}{|c|}{ Area (\%) } \\
\hline & & \multicolumn{2}{|c|}{ August } & \multicolumn{2}{|c|}{ January } \\
\hline & & $8 \mathrm{~h}$ & $16 \mathrm{~h}$ & $8 \mathrm{~h}$ & $16 \mathrm{~h}$ \\
\hline 1,8-cineole & 1,003 & 1.21 & 1.20 & 1.22 & 1.21 \\
\hline Linalool & 1,082 & 25.03 & 24.03 & 21.24 & 21.24 \\
\hline 4-terpineol & 1,173 & 1.01 & 1.03 & 1.31 & 1.32 \\
\hline$\alpha$-terpineol & 1,187 & 1.02 & 1.07 & 1.07 & 1.06 \\
\hline$Z$-citral(neral) & 1,242 & 3.27 & 4.79 & 4.88 & 4.89 \\
\hline$E$-citral (geraniol) & 1,276 & 7.49 & 8.45 & 8.46 & 8.43 \\
\hline Undecan-2-ona & 1,300 & 1.32 & 1.27 & 1.45 & 1.45 \\
\hline Eugenol & 1,380 & 32.67 & 32.64 & 32.61 & 33.24 \\
\hline Metyl eugenol & 1,420 & 3.44 & 3.42 & 3.57 & 3.53 \\
\hline$\alpha$-bergamotene & 1,461 & 1.59 & 1.61 & 1.61 & 1.47 \\
\hline$E$ - $\beta$-farnesene & 1,476 & 1.03 & 1.02 & 1.09 & 1.07 \\
\hline $\mathrm{NI}^{(2)}$ & 1,514 & 2.98 & 2.97 & 3.87 & 3.59 \\
\hline NI & 1,619 & 1.13 & 1.10 & 1.14 & 1.12 \\
\hline NI & 1,670 & 5.86 & 5.43 & 5.53 & 5.53 \\
\hline Torreiol ( $\delta$-cadinol) & 1,709 & 1.30 & 1.32 & 1.32 & 1.32 \\
\hline Hexadecan-1-ol (cetal) & 1,867 & 2.82 & 2.81 & 2.83 & 2.82 \\
\hline NI & 1,925 & 1.04 & 1.01 & 1.02 & 1.02 \\
\hline Palmitic acid & 1,935 & 5.78 & 4.83 & 5.79 & 5.69 \\
\hline
\end{tabular}

(1)Data are means of three replications; there was no significant difference among treatments in each row. ${ }^{(2)}$ Not identified. less durability. Lange \& Cameron (1994) report the maintenance of visual quality of sweet basil for 12 days when shoots were stored at $15^{\circ} \mathrm{C}$.

Basil infusion is used mainly against respiratory infections and stomach pains. Although the plants retained their green color and good visual aspect, their medical and spice quality might have been jeopardized due to the decrease of oil content during storage. The decrease in the essential oil content of basil plants during the days of storage is an important piece of information

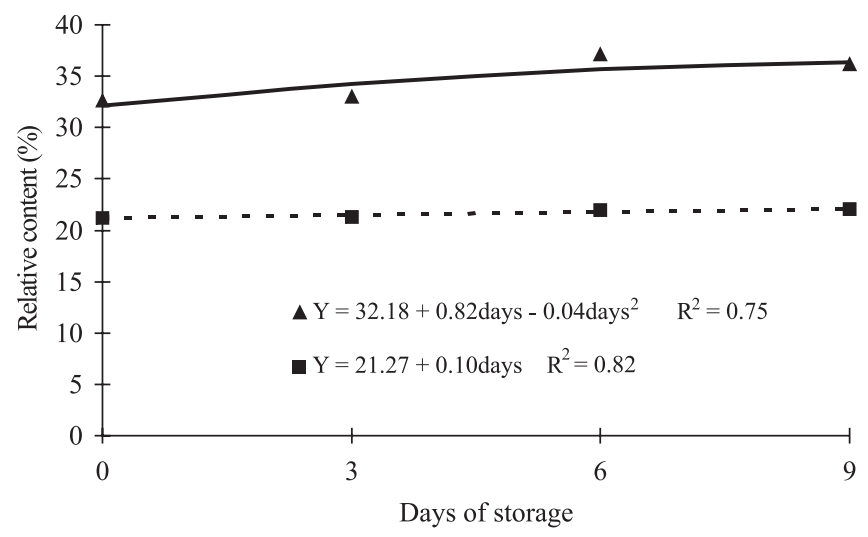

Figure 2. Eugenol ( $\mathbf{\Delta})$ and linalool $(\boldsymbol{\square})$ relative content in basil essential oil along storage at $10^{\circ} \mathrm{C}$. Data are means of two cropping seasons, two day hours and of three repetitions during the storage periods.

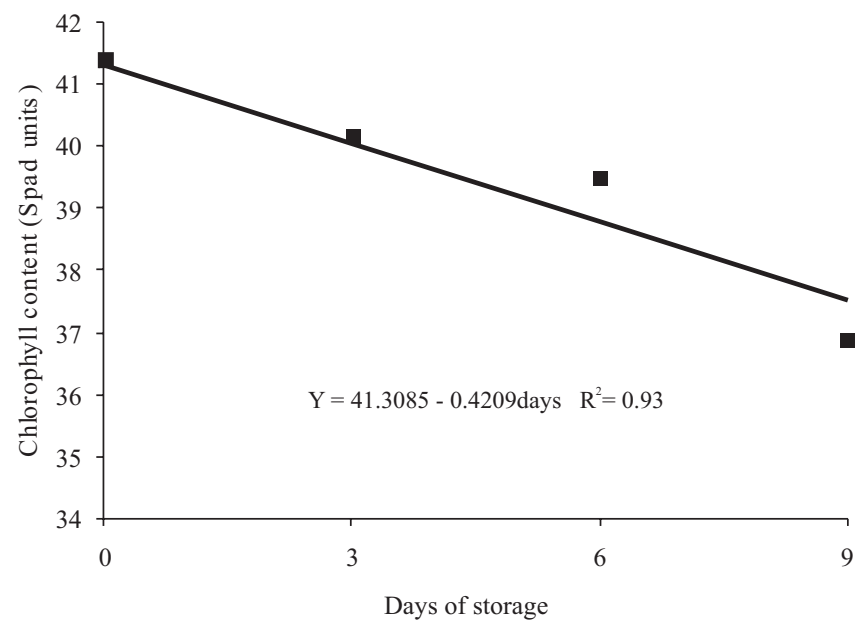

Figure 3. Chlorophyll content in fresh basil shoots along storage at $10^{\circ} \mathrm{C}$. Data are means of two cropping seasons and two day hours and of three repetitions during the storage periods. 
for the consumer. Either in the aisles of a supermarket or kept under refrigeration, the product looses quality along the days and must be consumed in greater quantities when medical or seasoning effect is expected.

When the PVC package was used, the quality of the product was retained for 6 days. Cantwell \& Reid (1994) report that both the PVC package and the temperature of $10^{\circ} \mathrm{C}$ enlarge the trading period of the product, once basil is highly perishable and its durability is inferior to 3 days when stored at room temperature. On the other hand, Lange \& Cameron (1997) found only 4 days of shelf life, when shoots were kept at $5^{\circ} \mathrm{C}$, due to chilling injury.

Plants were in early flowering stage in both seasons and Bahl et al. (2000) report that essential oil of basil at flowering stage is richer in linalool than in methyl chavicol, while plants at vegetative stages present greater content of methyl chavicol. Plant height and shoot selection can explain the high eugenol content. Miele et al. (2001a, 2001b) report that methyl eugenol is predominant in short plant and on low plant parts, while eugenol is prevalent in taller plants and upper plant parts, the ones harvested and analyzed.

The pathogenic microorganisms load was under the required sanitary level, indicating that the product is in good hygienic-sanitary conditions. This means that hygienic measures adopted in the handling of the product, such as the use of gloves, caps, aprons and masks, were adequate in the experiment. In addition the water used in the reduction of the field heat of the samples might

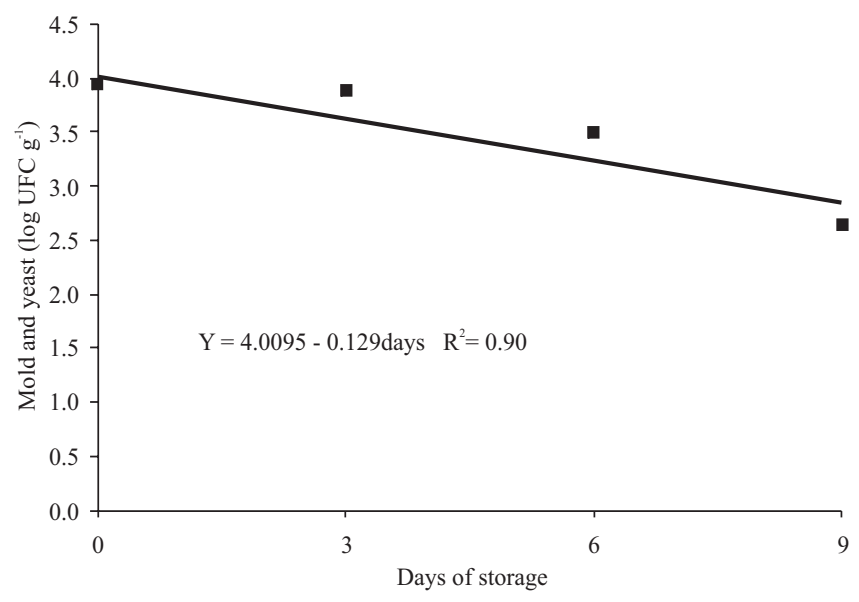

Figure 4. Logarithm of the number of yeasts and molds in fresh basil harvested in January along storage at $10^{\circ} \mathrm{C}$. Data from three repetitions. have helped in the superficial cleaning of the product. The use of a furrow irrigation method might also have had a positive contribution, since the water is conducted directly to the roots and has no contact with the leaves.

The decrease in the contamination by moulds and yeasts during the first 9 days of storage may be related to the storage at $10^{\circ} \mathrm{C}$, associated to the protecting package and essential oil composition.

Microorganisms reduce their activity at low temperature, and therefore, their proliferation and alteration in the food is prevented. In the respiratory process, microorganisms consume $\mathrm{O}_{2}$ and release $\mathrm{CO}_{2}$ in the atmosphere; along the storing period, there is an accumulation of $\mathrm{CO}_{2}$ in the atmosphere. Therefore, the environment disfavors the growth of obligate aerobic microorganisms, such as molds, which grow in positive redox potential, using oxygen as the final electrons acceptor of their respiratory chain (Banwart, 1989). The same does not occur with facultative anaerobes, such as $S$. aureus and yeasts, which use oxygen as the final acceptor when it is available; when it is not, many organic and inorganic substances are used. However, this microorganism was absent in the product since its origin.

The chemical constitution of the essential oil is another important factor to be considered. There are reports of antimicrobial activities of basil essential oil and its major components eugenol, linalool and methyl chavicol against Gram-positive and Gram-negative bacteria as well as yeasts and molds (Suppakul et al., 2003) and other microorganisms (Kim et al., 1995). Although Malmsten et al. (1991) report that the lethal effect of storage time was not clearly shown when herbs were packed in oxygen-containing packages, the increase of eugenol and linalool content and the release of essential oil to the package environment might have contributed to reduced contamination, while reducing its content in basil tissue.

\section{Conclusions}

1. There is a decrease in the contents of chlorophyll and essential oil along the days of basil shoot storage, accompanied by an increase in eugenol and linalool content.

2. Storage at $10^{\circ} \mathrm{C}$ decreases essential oil and chlorophyll content and reduces mold and yeast colonies.

3. The process of handling and conservation adopted is efficient in keeping the microbiological quality until 9 days after basil storage at $10^{\circ} \mathrm{C}$ in PVC packages. 


\section{Acknowledgement}

To CNPq, for financial support to research.

\section{References}

ADAMS, R.B. Identification of essential oil components by gas chromatography/mass spectroscopy. Illinois: Allured Publ., 1995. 468p.

BAHL, J.R.; GARG, S.N.; BANSAL, R.P.; NAQVI, A.A.; SINGH, V.; KUMAR, S. Yield and quality of shoot essential oil from the vegetative, flowering and fruiting stage crops of Ocimum basilicum cv. Kusumohak. Journal of Medicinal and Aromatic Plants, v.22, p.743-746, 2000.

BANWART, G.J. Basic food microbiology. $2^{\text {nd }}$ ed. New York: Van Nostrand Reinhold, 1989. 773p.

CANTWELL, M.I.; REID, M.S. Postharvest physiology and handling of fresh culinary herbs. Journal of Herbs, Spices and Medicinal Plants, v.1, p.93-127, 1994.

GANG, D.R.; WANG, J.; DUDAREVA, N.; NAM, K.H.; SIMON, J.E.; LEWINSOHN, E.; PICHERSKY, E. An investigation of the storage and biosynthesis of phenylpropenes in sweet basil. Plant Physiology, v.125, p.539-555, 2001.

KAMADA, T.; CASALI, V.W.D.; BARBOSA, L.C.A.; FORTES, I.C.P.; FINGER, F.L. Plasticidade fenotípica do óleo essencial em dois acessos de manjericão (Ocimum basilicum L.). Revista Brasileira de Plantas Medicinais, v.1, p.13-22, 1999.

KAYS, E.J. Postharvest physiology of perishable plant products. New York: AVI Book, 1991. 532p.

KIM, J.M.; MARSHALL, M.R.; WEI, C. Antibacterial activity of some essential oil components against foodborn pathogens. Journal of Agriculture and Food Chemistry, v.43, p.28392845, 1995.

LANGE, D.L.; CAMERON, A.C. Postharvest shelf-life of sweet basil (Ocimum basilicum). HortScience, v.29, p.103, 1994.

LANGE, D.L.; CAMERON, A.C. Pre and postharvest temperature conditioning of greenhouse-grown sweet basil. HortScience, v.32, p.114-116, 1997.

LEWINSOHN, E.; ZIV, R.I.; DUDAI, N.; TADMOR, Y.; LASTOCHKIN, E.; LARKOV, O.; CHAIMOVITSH, D.; RAVID, U.; PUTIEVSKY, E.; PICHERSKY, E.; SHOHAM, Y. Biosynthesis of estragole and methyl-eugenol in sweet basil (Ocimum basilicum L.): developmental and chemotypic association of allylphenol O-methyltransferase activities. Plant Science, v.160, p.27-35, 2000.

LUENGO, R.F.A.; LANA, M.M. Processamento mínimo de hortaliças. Brasília: Embrapa-CNPH, 1997. 4p. (Comunicado Técnico, 2).
MALMSTEN, T.; PAAKKONEN, K.; HYVONEN, L. Packaging and storage effects on microbiological quality of dried herbs. Journal of Food Science, v.56, p.873-875, 1991.

MARTINS, E.R.; CASALI, V.W.D.; BARBOSA, L.C.A.; CARAZZA, F. Essential oil in the taxonomy of Ocimum selloi Benth. Journal of the Brazilian Chemical Society, v.8, p.29-32, 1997. MEIR, S.; RONEN, R.; LURIE, S.; PHILOSOPH-HADAS, S. Assessment of chilling injury during storage: chlorophyll fluorescence characteristics of chilling-susceptible and triazole-induced chilling tolerant basil leaves. Postharvest Biology and Technology, v.10, p.213-220, 1997.

MIELE, M.; DONDERO, R.; CIARALLO, G.; MAZZEI, M. Methyleugenol in Ocimum basilicum L. cv. Genovese Gigante. Journal of Agriculture and Food Chemistry, v.49, p.517-521, 2001a.

MIELE, M.; LEDDA, B.; FALUGI, C.; MAZZEI, M. Methyleugenol and eugenol variation in Ocimum basilicum cv. Genovese Gigante in greenhouse and in vitro. Journal of Biological Research, v.77, p.43-50, $2001 \mathrm{~b}$.

NACAR, S.; TANSI, S. Chemical components of different basil (Ocimum basilicum L.) cultivars grown in Mediterranean regions in Turkey. Israel Journal of Plant Sciences, v.48, p.109-112, 2000.

PHILOSOPH-HADAS, S.; MEIR, S.; AKIRI, B.; KANNER, J. Oxidative defense systems in leaves of three edible herbs species in relation to their senescence rates. Journal of Agriculture and Food Chemistry, v.42, p.2376-2381, 1994.

RIBEIRO JUNIOR, J.I. Análises estatísticas no SAEG. Viçosa: Ed. UFV, 2001. 301p.

SHALABY, A.S.; EL GAMASY, A.M.; EL GENGAIHI, S.E.; KHATTAB, M.D. Post harvest studies on herb and oil of Mentha arvensis L. Egyptian Journal of Horticulture, v.15, p.213-224, 1988.

SUPPAKUL, P.; MILTZ, J.; SONNEVELD, K.; BIGGER, S.W. Antimicrobial properties of basil and its possible application in food packaging. Journal of Agriculture and Food Chemistry, v.51, p.3197-3207, 2003.

UNDERHILL, S.J.R.; CRITCHLEY, C. Cellular localization of polyphenol oxidase and peroxidase activity in Litchi chinensis Sonn. pericarp. Australian Journal of Plant Physiology, v.22, p.627632, 1995.

VANDERZANT, C.; SPLITTSTOESSER, D.F. Compendium of methods for the microbiological examination of foods. $3^{\text {rd }}$ ed. Washington: APHA, 1992. 867p.

VIEIRA, R.F.; SIMON, J.E. Chemical characterization of basil (Ocimun basilicum L.) found in the markets and used in traditional medicine in Brazil. Economical Botany, v.54, p.207-216, 2000.

WEST, C.A. Terpene biosynthesis and metabolism. In: DENNIS, D.T.; TURPIN, D.H. (Ed.). Plant physiology, biochemistry and molecular biology. London; Essex: Longman Scientific \& Technical, 1990. p.353-370.

Received on May 14, 2004 and accepted on November 19, 2004 